\title{
Připravenost pedagogických pracovníků základních škol na výuku dětí s Aspergerovým syndromem
}

\section{Zdeňka Kozáková, Veronika Pavlíčková}

\begin{abstract}
Abstrakt
Příspěvek prezentuje výsledky výzkumu, který se zabýval zkušenostmi pedagogických pracovníků s výukou dětí s Aspergerovým syndromem na prvním stupni základních škol. Hlavním cílem výzkumu bylo prostřednictvím kvalitativních technik sběru dat (formou polostrukturovaného rozhovoru) zjistit, analyzovat, interpretovat a deskribovat míru připravenosti a zkušeností pedagogických pracovníků se společným vzděláváním žáků s Aspergerovým syndromem. Do výzkumu se zapojilo 10 pedagogických pracovníků základních škol v Olomouckém kraji, kteří již měli zkušenost s výukou dětí s Aspergerovým syndromem. Analýza dat byla provedena prostřednictvím zakotvené teorie. Z výsledků vyplynula potřeba zaměřit se na vytvoření komfortnějšího prostředí pro pedagogické pracovníky a na realizaci efektivnějšího systému dalšího vzdělávání pracovníků.
\end{abstract}

Klíčová slova: Aspergerův syndrom, připravenost pedagogických pracovníků, inkluzivní vzdělávání.

\begin{abstract}
The article presents experience of elementary school pedagogues with teaching children with Asperger's syndrome. The main aim was to find out, analyse, interpret and describe readiness for teaching children with the syndrome based on quantitative research and semi-structured interview. The research itself was based in elementary school in Olomouc region and ten pedagogues with already established experience with teach-
\end{abstract}


ing children with Asperger's syndrome were involved. Analysis of collected data was based on Grounded theory. The results showed that it is necessary to create comfortable environment for the pedagogues. Moreover, it is crucial to develop further education of all pedagogical workers involved in teaching children suffering Asperger's syndrome.

Keywords: Aspergers syndrome, readiness of pedagogical workers, inklusive education, pedagogical workers training.

\section{Úvod}

Aspergerův syndrom (dále jen AS) se řadí mezi poruchy autistického spektra. Projevuje se především specifiky v komunikaci a v sociálním chování. Intelekt mají jedinci s AS $v$ průměru, někteří dokonce $v$ nadprůměru. Žáci s autismem a dalšími pervazivními vývojovými poruchami (dále jen PVP) bez mentálního postižení jsou v České republice vzdělávání podle Individuálního vzdělávacího plánu ve školách hlavního vzdělávacího proudu (Lechta, 2016).

Pro děti s Aspergerovým syndromem jsou charakteristická specifika, která se promítají do učení a chování a mohou představovat pro pedagogy obtí̌e z hlediska výuky. Tyto děti bývají nejednou interpretovány jako „nevychované“. Přitom je jejich chování často jen výsledkem nízké frustrační tolerance a potíží se čtením sociálních podnětů. Je tedy důležité, aby se pedagogové orientovali v problematice vzdělávání s Aspergerovým syndromem a rozpoznali nevhodné chování od projevů žáka s Aspergerovým syndromem (Myles, Hagen, Holverstott, Hubbard, Adreon, Trautman, 2016).

\section{Metody a přístupy ve vzdělávání dětí s Aspergerovým syndromem na základní škole}

V současné době se při vzdělávání dítěte s Aspergerovým syndromem využívá celá řada intervenčních programů, které jsou postaveny na silných stránkách jedince a respektují jeho vývojový model vzdělávání. Základem těchto strategií je strukturovaný př́istup, který je přizpůsoben individuálním potřebám žáka a prípadně doplněn dalšími strategiemi (Čadilová, Žampachová, 2012).

Jednou z metodik, využívaných při práci s dítětem s PAS v České republice, je strukturované učení, které vychází z TEACCH programu"11 a Loovasovy intervenční terapie.

TEACCH program vznikl v roce 1966 v Severní Karolíně v USA. Jedná se o modelový program péče o lidi s autismem $v$ každém věku. Vychází z úzké spolupráce odborníků s rodiči, kdy rodiče působí jako koterapeuti a spolupracovníci odborníků. 
Systém strukturovaného učení pomáhá dětem pochopit okolní svět, vytvárí pro děti prostředí, ve kterém mohou být úspěšné a rozumí mu. Mezi základní principy strukturovaného učení řadíme individualizaci, strukturalizaci, vizualizaci a motivaci (Adamus, Žampachová, 2016).

Mezi další využívané metody patří např. aplikovaná behaviorální analýza (dále jen $A B A)$. Jedná se o intervenční terapii, která se zaměřuje na chování a proces učení. Tato metoda umožňuje dětem s PAS lépe zvládat vzdělávání, a to pomocí rozdělení obsahu do menších, lépe pochopitelných, celkủ. Tyto menší celky mají jasně vymezen postup v jednotlivých krocích, které postupují od jednoduššího ke složitějšímu. Nejvýznamnějším principem metody ABA je individuální přístup (Čadilová, Žampachová, 2012).

\section{Připravenost pedagogických pracovníků}

V mnoha vyspělých zemích je v současné době přijímán názor, že úroveň vzdělání žákư je do jisté míry ovlivněna osobností učitelů, tedy i jejich připravenosti na náročnou profesi (Průcha, 2009).

Psychologický slovník nedefinuje přímo pedagogickou připravenost, ale připravenost učební, kterou definuje jako: „specifickou připravenost řešit velmi rychle všechny učební úkoly dané třídy, která vzniká opakováním řešení problémů určitého typu a na základě řešení úkolů nižšího typu se vytvárí zpưsobilost, která umožňuje nebo usnadňuje učení vyššiho typu" (Hartl, Hartlová, 2015).

Další pojmy, které jsou spojovány s připraveností pedagogů, jsou pedagogická dovednost a pedagogická kompetence. Pedagogický slovník (Průcha, Walterová, Mareš, 2009) vymezuje pedagogickou dovednost jako: „... . součást profesních kompetencí učitelů a pedagogických pracovníků, předpoklad pro výkon pedagogických povoláni" (Dytrtová, Krhutová, 2009). Pojem kompetence učitele definuje Pedagogický slovník jako (Průcha Walterová, Mareš, 2009): „... soubor vědomostí, dovedností, postojů a hodnot důležitých pro výkon učitelské profese. Vztahují se k profesní, obsahové a osobnostní složce standardu učitelství." Rozlišujeme kompetence profesní a osobnostní.

\section{Metodologie výzkumu}

Cílem výzkumného šetření bylo prostřednictvím kvalitativních technik sběru dat (formou polostrukturovaného rozhovoru) zjistit, analyzovat, interpretovat a deskribovat připravenost a zkušenosti pedagogických pracovníků se společným vzděláváním žáků s Aspergerovým syndromem.

Základní výzkumná otázka byla stanovena následovně: „Jak jsou pedagogičtí pracovníci základních škol osobnostně i profesně připraveni na vzdělávání žáků s Asperge- 
rovým syndromem?" Základní výzkumná otázka byla dále rozvíjena těmito specifickými výzkumnými otázkami:

- Jak v současné době vnímají pedagogičtí pracovníci jejich připravenost na výuku dětí s AS?

- Jaké jsou znalosti pedagogických pracovníků ohledně tvorby prostředků, které zefektivňují vzdělávání žáka s AS?

- Jak pedagogičtí pracovníci hodnotí spolupráci se speciálně pedagogickým centrem (SPC), s pedagogicko-psychologickou poradnou (PPP)?

- Jaký je osobní názor pedagogických pracovníků na vyhlášku č. 27/2016 Sb.?

Kritériem pro výběr výzkumného vzorku pedagogických pracovníků byla zkušenost se vzděláváním dětí s diagnostikovaným AS. Hledání vhodných recipientů probíhalo prostřednictvím oslovení vedoucích pracovníků základních škol Olomouckého kraje.

Výzkumné šetření bylo realizováno na Základní škole náměstí Míru 83, Kojetín. Jedná se o základní školu úplnou, která není specificky zaměřena. Počet žáků ve školním roce 2017/2018 je 455 žáků. Na základní škole je celkem 21 tříd, což činí průměrně 22 dětí na jednu třídu. (Plán práce školy: Školní rok 2017-2018) V současné době tuto školu navštěvují 4 žáci s Aspergerovým syndromem.

Zájem o výzkumné šetření projevilo deset pedagogických pracovníků. Jednalo se o pět pedagogů vyučujících na prvním stupni ZŠ, tři pedagogy vyučujících na druhém stupni ZŠ a jednu asistentku pedagoga. Věk pedagogických pracovníků byl v rozmezí 36-53 let. Rozhovor byl realizován také s vedoucím pracovníkem školy a s koordinátorkou pro oblast autismu.

Vzhledem k tématu byla zvolena kvalitativní metoda výzkumu. Sběr dat v rámci výzkumu byl prováděn formou individuálního hloubkového polostrukturovaného rozhovoru. Hloubkový rozhovor můžeme definovat jako nestandardizované dotazování, při kterém se jeden badatel dotazuje jednoho účastníka výzkumu, a to za pomocí několika otevřených otázek (Švaříček, Šed’ová, 2007).

Údaje získané za pomocí polostrukturovaných rozhovorů byly analyzovány a interpretovány metodou zakotvené teorie (Strauss, Corbin, 1999). Výsledkem otevřeného kódování bylo 10 kategorií:

- uplatňované přístupy k žákům s Aspergerovým syndromem,

- specifika žáků s Aspergerovým syndromem,

- připravenost pedagogických pracovníků,

- využívané zdroje informací,

- Individuální vzdělávací plán a Plán pedagogické podpory,

- $\quad$ spolupráce se školským poradenskými zařízeními,

- spolupráce s rodiči žáků s Aspergerovým syndromem,

- náročnost vzdělávání žáků s Aspergerovým syndromem, 
- znalost vyhlášky č. 27/2016 Sb.,

- supervize.

V dalším textu se zaměříme na kategorii „Připravenost pedagogických pracovníků“.

\section{Interpretace výsledků výzkumu}

Za centrální kategorii byla vybrána třetí kategorie s názvem Připravenost pedagogických pracovníků. Tuto kategorii budeme v dalším textu charakterizovat ve vztahu k ostatním.

Připravenost pedagogických pracovníků a uplatňované přístupy k žákům s Aspergerovým syndromem

Z důvodu neznalosti využívaných pomůcek a didaktických materiálů při výuce žáků s AS uváděli pedagogičtí pracovníci, že se necítí příliš připraveni po odborné stránce na výuku dětí s AS. Ocenili by více nápadů a námětů, jak s těmito dětmi pracovat.

Z rozhovorů vyplynula důležitost správného navázání vztahu s žákem a poznání jeho osobnosti. Uvádí, že jakmile osobnost pedagoga není připravena přijmout takového žáka, úspěšný vzdělávací proces není možný. Pedagogičtí pracovníci sdělovali, že po osobnostní stránce nemají problém se žákovi přizpůsobit.

\section{Připravenost pedagogických pracovníků a specifika žáků}

\section{s Aspergerovým syndromem}

Jestliže má být pedagogický pracovník připraven na výuku žákư s AS, je nezbytné, aby disponoval znalostmi o přístupu a specifických projevech těchto žáků. Bez těchto znalostí mohou pedagogičtí pracovníci vnímat žáka s AS jako problémového nebo nevychovaného.

Pedagogičtí pracovníci v rozhovorech uváděli, že nejvýraznějším specifickým projevem je rozdílná komunikace. Uváděli, že žáci při komunikaci používají knižní výrazy, nechápou ironii a humorné situace. Rovněž musí pedagogičtí pracovníci upravovat formu zadávání úkolů a ujištovat se, zda žák rozuměl zadání. Bez znalosti tohoto specifika chování mohou vnímat pedagogičtí pracovníci například neustálé dotazování se na zadání úkolu jako „provokaci“ žáka.

\section{Připravenost pedagogických pracovníků a využívané zdroje informací}

Připravenost pedagogických pracovníků na výuku žáků s AS souvisí taktéž se zdroji, odkud čerpají informace a s kvalitou těchto zdrojů. Jako nejčastěji uváděný zdroj informací se $v$ rozhovorech vyskytoval internet, a to z důvodu jeho snadné dostupnosti. Dále se v odpovědích objevovala odborná literatura, beletrie a televizní dokumenty, časopisy. 
Z rozhovorů vyplynulo, že by pedagogičtí pracovníci rádi zlepšili svoji informovanost a připravenost na výuku žáků s AS prostřednictvím školení a vzdělávacích kurzů na dané téma. Pozitivní v této oblasti je, že vedoucí pracovník školy uvedl, že v nejbližší době hodlá proškolit celý pedagogický sbor.

\section{Připravenost pedagogických pracovníků a Individuální vzdělávací plán} a Plán pedagogické podpory

Pokud je pedagogický pracovník třídním učitelem žáka s AS, je povinen v př́ípadě potřeby vytvořit Plán pedagogické podpory (PLPP) a jestliže má žák uznané podpůrné opatření 2.-5. stupně je potřeba vytvořit Individuální vzdělávací plán žáka (IVP).

Z rozhovoru vyplývá, že pedagogičtí pracovníci, kteří nemají zkušenost s tvorbou IVP nebo PLPP, se necítí dostatečně připraveni pro jeho tvorbu. Uvádějí, že by se obrátili například na zkušenějšího kolegu, PPP nebo SPC. Pedagogičtí pracovníci, jež mají zkušenost s tvorbou IVP a PLPP uváděli, že jej tvořili sami, nebo s pomocí SPC. Často také vycházeli ze zprávy a doporučení ze školských poradenských zařízení při tvorbě cílů.

\section{Připravenost pedagogických pracovníků a spolupráce se školským poradenskými zařízeními}

Připravenost pedagogických pracovníků na výuku dětí s AS značně souvisí s jejich spoluprací se školskými poradenskými zařízeními. Z rozhovorů vyplývá, že pedagogičtí pracovníci pocitují větší podporu od pracovníků SPC než od pracovníků PPP. Kladně hodnotili SPC především z toho důvodu, že instruují a edukují pedagogické pracovníky přímo ve školách. Co se týká spolupráce s PPP, z rozhovorů vyplývá, že se jednalo spiše o anonymní komunikaci pomocí doporučení, zpráv a e-mailu.

\section{Připravenost pedagogických pracovníků a spolupráce s rodiči žáků}

\section{s Aspergerovým syndromem}

Spolupráce pedagogických pracovníků s rodiči je při vzdělávání žáka s AS důležitá. Je vhodné dítěti nastolit stejné podmínky v domácím i ve školním prostředí. Pedagogičtí pracovníci jsou často mezi těmi, kteří si mezi prvními všímají specifických projevů žáka a doporučují rodičům vyšetření ve školském poradenském zařízení.

Z rozhovorů vyplývá, že pedagogičtí pracovníci mají zkušenosti s odmítavým postojem rodičů, kteří si nechtějí přiznat, že by jejich dítě mohlo mít diagnózu Aspergerova syndromu. Se spoluprací s rodiči pedagogickým pracovníkům vypomáhali pracovníci SPC. Koordinátorka pro oblast autismu uvádí, že ideální je týmová spolupráce školy, rodičů a poradenského zařízení. 


\section{Připravenost pedagogických pracovníků a náročnost vzdělávání žáků}

\section{s Aspergerovým syndromem}

Jestliže pedagogičtí pracovníci nemají znalosti v oblasti vhodných přístupů a metod pro vzdělávání žáků s AS, mohou pocit’ovat zvýšenou náročnost při práci s žáky s AS. Z rozhovorů vyplývá, že pokud je osobnost pedagogického pracovníka schopna a připravena přijmout a určitým způsobem se „přizpůsobit“ dítěti, následně nepocituje zvýšenou pracovní zátěž, ale naopak může takový žák obohatit celou třídu.

S náročností vzdělávání žáků s AS souvisí i připravenost na rưzné situace, které mohou nastat. Dále pedagogičtí pracovníci uvádějí, že náročnost práce stoupá z důvodu, že vyučování musí být sestaveno tak, aby vyhovovalo jak žákovi s AS, tak i intaktním spolužákům.

\section{Připravenost pedagogických pracovníků a znalost vyhlášky č. 27/2016 Sb.}

Pedagogičtí pracovníci by měli být obeznámeni s vyhláškou číslo č. 27/2016 Sb., aby byli připraveni poskytovat podpưrná opatření pro žáky s AS. Z rozhovorů vyplývá, že pedagogičtí pracovníci neznají znění vyhlášky, ale vědí, kde ji dohledat, popřípadě mají u sebe její výtah.

Dále z rozhovorů vyplývá, že vyhláška č. 27/2016 Sb., má podle dotazovaných pedagogů své „výhody“ i nedostatky. Jako kladný přínos výše uvedené vyhlášky byla uvedena finanční podpora pro podpůrná opatření. Mezi záporné stránky této vyhlášky přiřazují pedagogičtí pracovníci nárůst administrativní činnosti, a to pro třídní učitele, ředitele školy a výchovné poradce.

\section{Připravenost pedagogických pracovníků a supervize}

Pedagogičtí pracovníci v rozhovorech uváděli, že se necítí být po odborné stránce připraveni na výuku dětí s AS, a proto by uvítali formu supervize ve školství. Z rozhovorů vyplývá, že by supervizi považovali jako přínos i z hlediska osobního rozvoje. Uváděli, že se sami necítí jako odborníci na problematiku poruch autistického spektra a bylo by příjemné mít se na koho obrátit v případě problému.

\section{Závěr}

Výsledky výzkumného šetření poukazují na nízkou odbornou připravenost pedagogických pracovníků základních škol na výuku dětí s Aspergerovým syndromem. Pedagogičtí pracovníci uváděli, že hlavním nedostatkem jejich odborné připravenosti je neznalost př́stupů k dětem s Aspergerovým syndromem, vhodných pomůcek a možností úpravy didaktických materiálů pro tyto děti. Co se týká osobnostní připravenosti, pedagogičtí pracovníci v rámci výzkumu sdělovali, že z hlediska osobnostní stránky se 
cítí být připraveni pracovat $s$ těmito dětmi, jsou ochotni a nečiní jim žádné potíže se dítěti určitým způsobem „přizpůsobit”.

Pedagogičtí pracovníci projevili určitou nespokojenost se změnami ve školské legislativě, které proběhly v roce 2016. Uváděli názor, že při tvorbě vyhlášky 27/2016 Sb., o vzdělávání žáků se speciálními vzdělávacími potřebami a žáků nadaných, byli vyslyšeni teoretičtí odborníci místo osob z praxe. Upozorňovali především na zvýšenou míru administrativní práce související s tvorbou Plánů pedagogické podpory a Individuálních vzdělávacích plánů.

Přispěvekje dedikován projektu Studentské grantové soutěže na Univerzitě Palackého v Olomouci: „Výzkum inkluze u osob se speciálními potrebami (IGA_PdF_2017_008)."

\section{Literatura}

Adamus, P., \& Žampachová, Z. (2016). Strategie uplatňované v edukaci žáků s poruchami autistického spektra. Ostrava: Montanex.

Čadilová, V., \& Žampachová, Z. (2008). Strukturované učení: vzdělávání dětí s autismem a jinými vývojovými poruchami. Praha: Portál.

Čadilová, V., \& Žampachová, Z. (2012). Metodika práce se žákem s poruchami autistického spektra. Olomouc: Univerzita Palackého v Olomouci.

Dytrtová, R., Krhutová, M., \& Mareš, J. (2009). Učitel: př́íprava na profesi. Praha: Grada.

Hartl, P., \& Hartlová, H. (2015). Psychologický slovník. Třetí, aktualizované vydání. Praha: Portál.

Lechta, V. (Ed.). (2016). Inkluzivní pedagogika. Praha: Portál.

Miovský, M. (2006). Kvalitativní prístup a metody v psychologickém výzkumu. Praha: Grada.

Myles, B., Hagen, K., Holverstott, J., Hubbard, A., Adreon, D., \& Trautman, M. Life Journey Through Autism: An Educator's Guide to Asperger Syndrome. [Online]. Retrieved from https://researchautism. org/resources/an-educators-guide-to-asperger-syndrome/

Plán práce školy: Školní rok 2017-2018. [online], [cit. 2018-01-07]. Dostupné z: http://www.zskojetin. $\mathrm{cz} /$ ke-stazeni/dokumenty

Průcha, J. (Ed.). (2009). Pedagogická encyklopedie. Praha: Portál.

Průcha, J., Walterová, E., \& Mareš, J. (2009). Pedagogický slovník. 6., aktualiz. a rozš. vyd.. Praha: Portál. Strauss, A. L., Corbin, J., \& Mareš, J. (1999). Základy kvalitativního výzkumu: postupy a techniky metody zakotvené teorie. Brno: Sdružení Podané ruce.

Švaříček, R., \& Šed’ová, K. (2007). Kvalitativní výzkum v pedagogických vědách. Praha: Portál.

\section{Kontakt:}

Mgr. Zdeňka Kozáková, DiS., Ph.D.

Veronika Pavlíčková

Ústav speciálněpedagogických studií

Pedagogická fakulta Univerzity Palackého v Olomouci

Žižkovo nám. 5, 77140 Olomouc

E-mail: Zdenka.Kozakova@upol.cz; pavlickova-veronika@seznam.cz 